\title{
WIND FIELD OVER COMPLEX TERRAIN AND AIR QUALITY MODELING
}

\author{
Duong Ngoc HaI, Nguyen Van Diep, Nguyen The Duc \\ Institute of Mechanics, NCNST, Hanoi, Vietnam \\ LE TRINH \\ Environment Protection Center VITTEP, Ho Chi Minh City, Vietnam
}

\section{Introduction}

The wind field is the second component in the chain: Source - Propagation - Object, and plays an important role in the atmospheric pollution processes. But determining the exact wind field for numerical air pollution modeling always is a difficult problem. In the numerous codes the semi-empirical model based on Gaussian or Berliand conceptions and using the uniform wind field in combination with observational and measurement data $[1,2]$ is applied to simulate the pollutant transport due to convection and its dispersion due to turbulence. In fact, this kind of model, which requests statistical meteorological information, is simple, easy to use, but normally applicable for small spatial area (small scale, some kilometers from pollutant emission sources). In the area with complex terrain, for example, mountain and coastal zones the wind field changes from time to time and usually has non-uniform distribution. Therefore in those cases the simplified model listed above will lead to a significant error.

In the paper the mesoscale wind field simulation and air quality modeling results using three dimensional numerical package LADM [3] and the influence of complex terrain (raising mountain and coastal line) on the wind field and pollutant propagation for some examples such as northeast (Hai phong, Quang ninh) and central (Dung quat) provinces of Vietnam are presented. All calculations are implemented on PC Pentium 100 at the Institute of Mechanics - NCNST (Hanoi).

\section{Mathematical models}

\subsection{Wind field model}

Governing equations

In order to simulate the atmospheric turbulent motion the basic equations of thermo- and hydrodynamics taken into account of astronomical and meteorological conditions such as the short wave radiation (changing from time to time during the year and depending on the astronomical angle), Coriolis force, cloud (cloud type, level cover and etc.) and influence of the thermo-hydrodynamical processes, surface properties and etc. are used and closed by the K-theory.

In general, the system of equations, including the equation of mass conservation, impulse conservation in vector form, energy conservation in the form of the thermal conductivity equation and equation for humidity change, has the following form:

$$
\begin{aligned}
& \frac{D \rho}{D t}+\rho(\nabla \cdot \bar{v})=0 \\
& \frac{D \bar{v}}{D t}+[\bar{\Omega} \times \bar{v}]=-\frac{1}{\rho} \operatorname{grad} p-g \bar{k}+\left(\nabla \cdot K_{d} \nabla\right) \bar{v} \\
& \frac{D \theta}{D t}=\left(\nabla \cdot K_{\theta} \nabla\right) \theta+q_{r} \\
& \frac{D c_{h}}{D t}=\left(\nabla \cdot K_{h} \nabla\right) c_{h}
\end{aligned}
$$


where the symbols are used traditionally and, respectively, $\rho, p, \bar{v}$ are a density, pressure and vector velocity; $\theta$ is a temperature potential; $K$ is a diffusion coefficient; $q_{r}$ is a thermal flux due io radiation; $c_{h}$ is a humidity and $g$ is the gravitational coefficient.

The temperature $T$ can be presented through $\theta$ in the following manner:

$$
T=\theta\left(\frac{p}{p_{*}}\right)^{R / C_{p}}
$$

Nhere $R$ is the gas constant; $C_{p}$ is a heat capacity at constant pressure; $p_{*}$ is the standard pressure ind equal $1000 \mathrm{mbar}$.

In order to integrate numerically the system of equations (2.1)-(2.5) is transformed using uydrostatic assumption into the system of coordinates $\left(x, y, \sigma=p / p_{s}\right)$ where $p_{s}$ is surface pressure.

Boundary conditions

"Lateral:

The wind field calculation is implemented using "nest" techniques. In the framework of this iechniques the wind field is simulated for the nests one smaller another. The first calculation is mplemented for the biggest nest with the zero-gradient conditions at the boundary. The calculation 'esults are used as boundary conditions for the next smaller nest, and the process is continued until he smallest nest which we are interested in. Normally the biggest nest has the size of $800 \mathrm{~km} \times$ $300 \mathrm{~km}$, and every the next nest has the half size of the previous nest.

' Surface:

The wind velocity at the surface is zero. The thermal, dynamical and moist conditions are ;iven depending on the surface material properties such as water, soil (clay, sand, rock etc.) and overing flora (soil-canopy). For the temperature the equation of the soil thermal conductivity is olved.

' Upper:

The height of the simulation box is $19700 \mathrm{~m}$ above the sea level. With this height the noneflection of upward propagating waves from the top of model is assumed.

Initial data

Besides elevation of the terrain above sea level, also needed are vertical profiles of wind and emperature at a point near the study region center. The wind profile must reffect the synoptic-scale ressure gradients and obtained from mean ground-level pressure charts and geopotential height harts at $1000 \mathrm{hPa}, 850 \mathrm{hPa}, 700 \mathrm{hPa}, 500 \mathrm{hPa}$ and etc. The initial data should be representative if the study region and applied at all grid columns.

The obtained system of equations (2.1)-(2.4) is solved by the finite difference method using the Irakawa C-grid, fractional time steps and the sweep procedure. The model run usually begins at nidnight to allow the wind to adjust to the terrain and to allow time for drainage flow to develop refore diurnal heating begins at sunrise. It is also advisable to run the model for 48 hours and nore, and compare predictions to observations during the second 24 hours, thus allowing time for he formation of mesoscale pressure gradients from the diurnal heating of the previous day.

\subsection{Pollutant dispersion}

In order to simulate the pollutant propagation process within the Lagrange conception the quation for the particle position determining is used:

$$
x_{i}(t+d t)=x_{i}(t)+\left[v_{i}(t)+v_{i}^{\prime \prime}(t)\right] d t
$$

vhere $v^{\prime \prime}$ is turbulent component of velocity determined by Langevin equation

$$
d v_{i}^{\prime \prime}=a_{i} d t+\left(C_{0} \varepsilon\right)^{1 / 2} d w_{i}
$$

nd Fokker-Planck equation:

$$
\frac{\partial a_{i} P_{E}}{\partial v_{i}^{\prime \prime}}=-\frac{\partial v_{i}^{\prime \prime}}{\partial x_{i}}+\frac{1}{2} C_{0} \varepsilon \frac{\partial^{2} P_{E}}{\partial v_{i}^{\prime \prime}}-\frac{\partial P_{E}}{\partial t}
$$


Here $a_{i}$ is an acceleration, $d v_{i}^{\prime \prime}$ is a change in turbulent velocity over the time interval $d t, \varepsilon$ is the rate of dissipation of turbulent kinetic energy, $C_{0}$ is a universal constant; $d w_{i}$ is a random variable which has a Gaussian distribution (mean 0 , variance $d t$ ) and $P_{E}$ is the probability density function representing the turbulence.

In convective (unstable) conditions for the top of the mixed layer and surface the condition used is the skewed memory reflection. The only boundary condition employed in stable conditions is at the ground where perfect reflection of a particle's velocity and position is assumed to occur. The height, at which particles are released through the simulation period, is determined from the bent-over plume rise equations.

The initial concentration is a font concentration. As the input data, the dispersion model uses the wind fields and turbulence parameters, obtained from the model presented in 2.1, to advect and diffuse the particles. These values are updated every ten minutes. For the pollutant source, it is necessary to specify emission characteristics needed for the plume rise calculations, such as the emission (stack) height, tlue gas speed and temperature, pollutant contains and etc.

The more detailed mathematical description of models and results of its verification (analysis of case studies and comparison with observations) can be seen in [3]. Note that for a single mountain the influence of the terrain on the wind field, maximum surface concentration and etc. can lead to a significant effect normally when the slopes are typically greater than 1:10.

\section{Wind field over some complex terrains}

The terrains structure is digitized and kept in the form of data file on a PC. For example, in Figs 1-5 the terrain structure maps of north east (Figs 1-4) and central (Fig. 5) provinces of Vietnam are presented. The iso-level contours indicate the heights with interval of $100 \mathrm{~m}$.

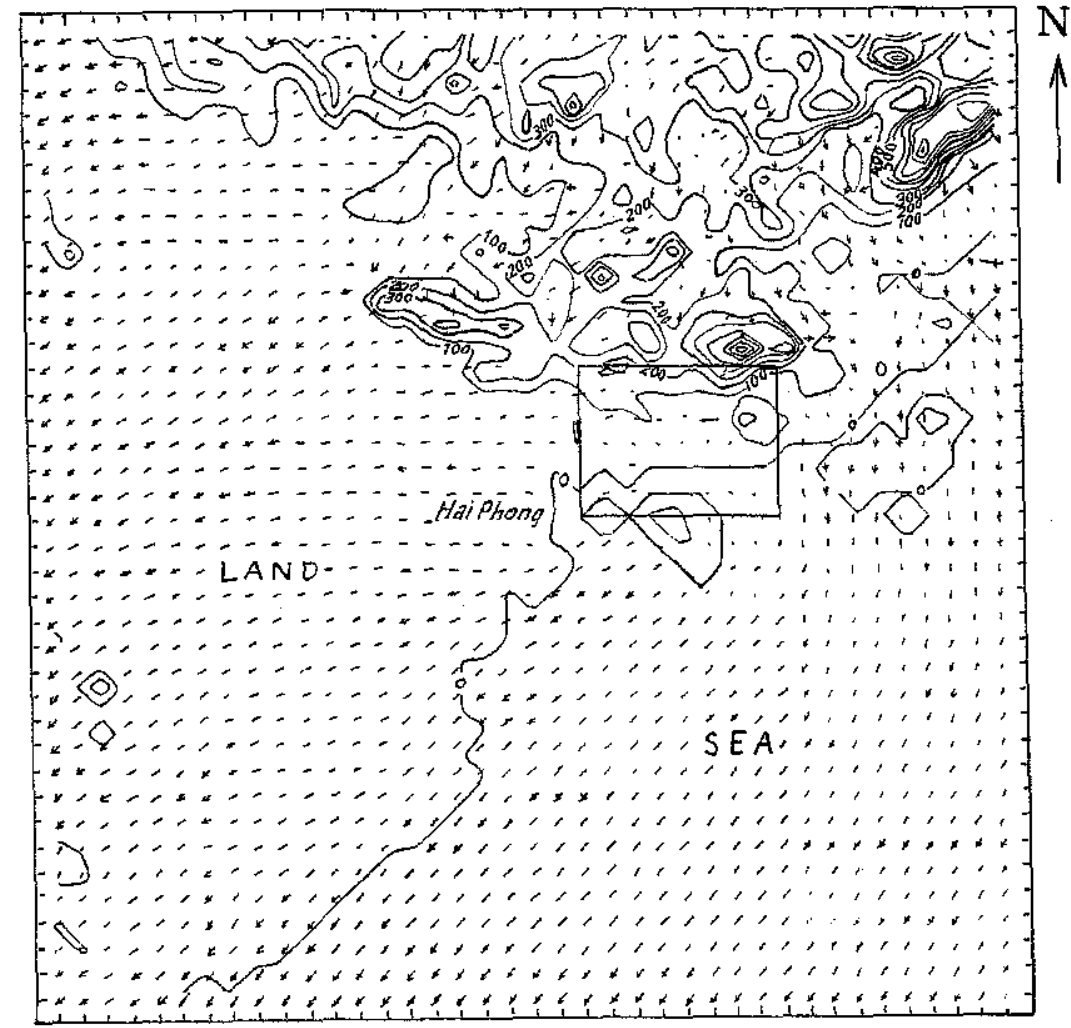

Fig. 1. Modeled wind fields $-06 \mathrm{~h}-10 \mathrm{~m}-$ Winter $\rightarrow 10 \mathrm{~m} / \mathrm{s}$ 


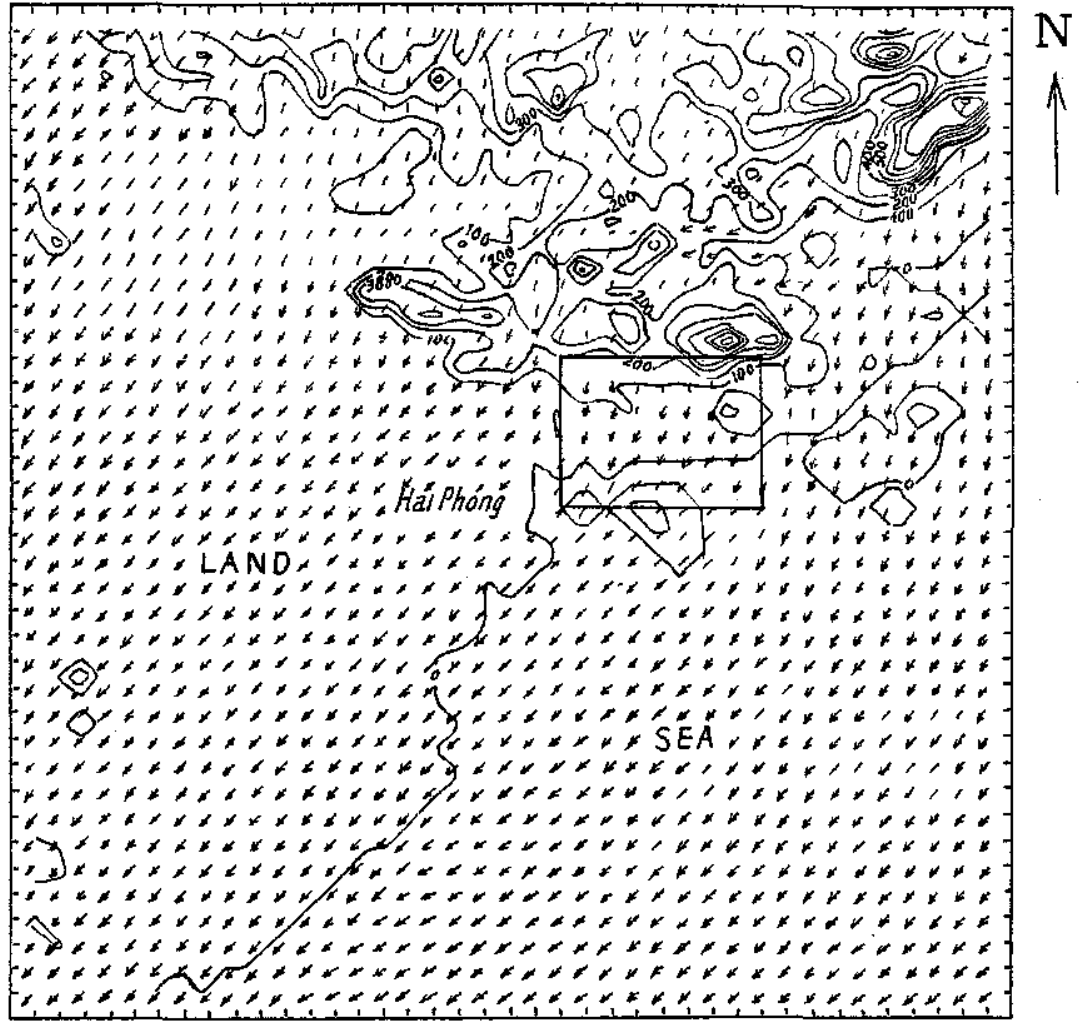

Fig. 2. Modeled wind fields $-11 \mathrm{~h}-10 \mathrm{~m}-$ Winter $\longrightarrow 10 \mathrm{~m} / \mathrm{s}$

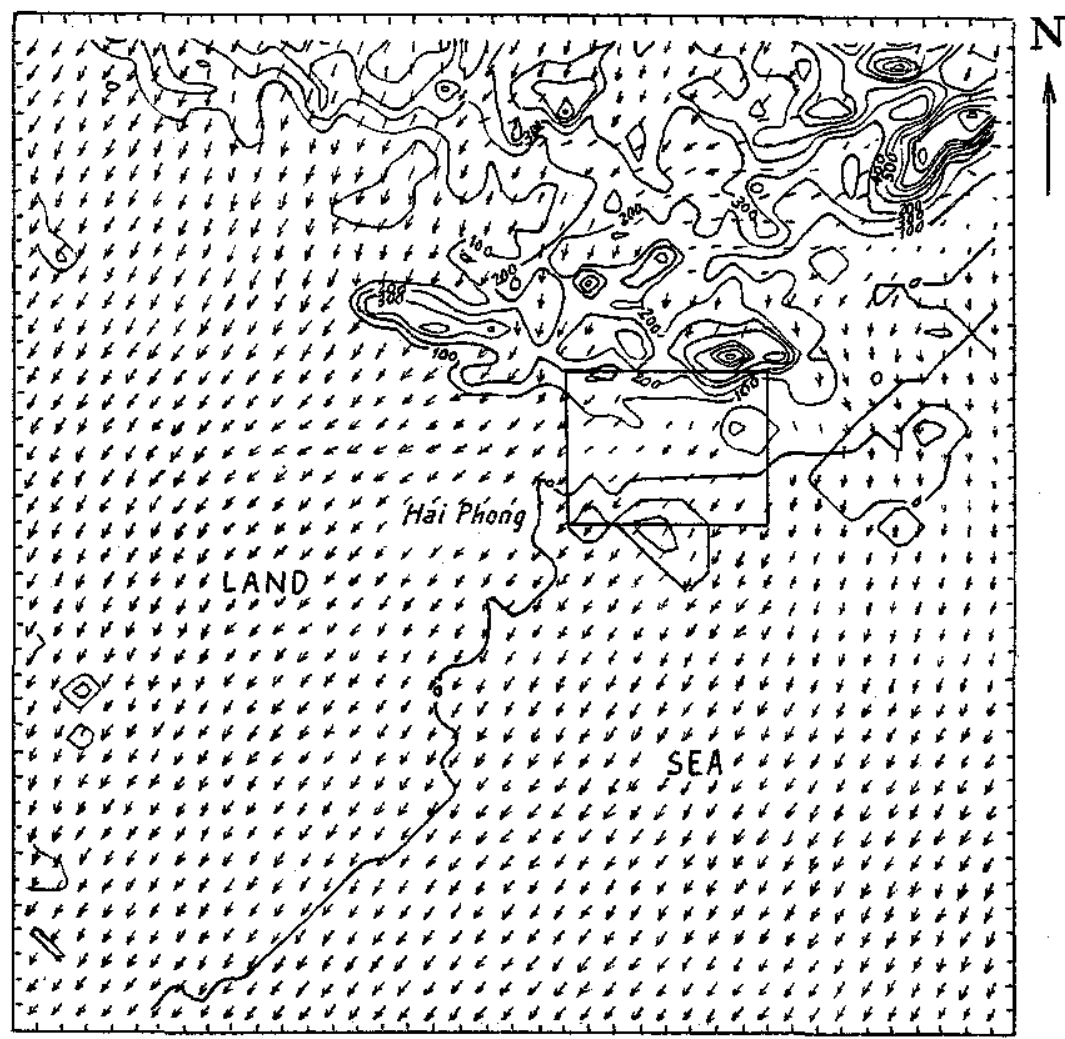

Fig. S. Modeled wind fields $-19 \mathrm{~h}-10 \mathrm{~m}-$ Winter $\rightarrow 10 \mathrm{~m} / \mathrm{s}$ 


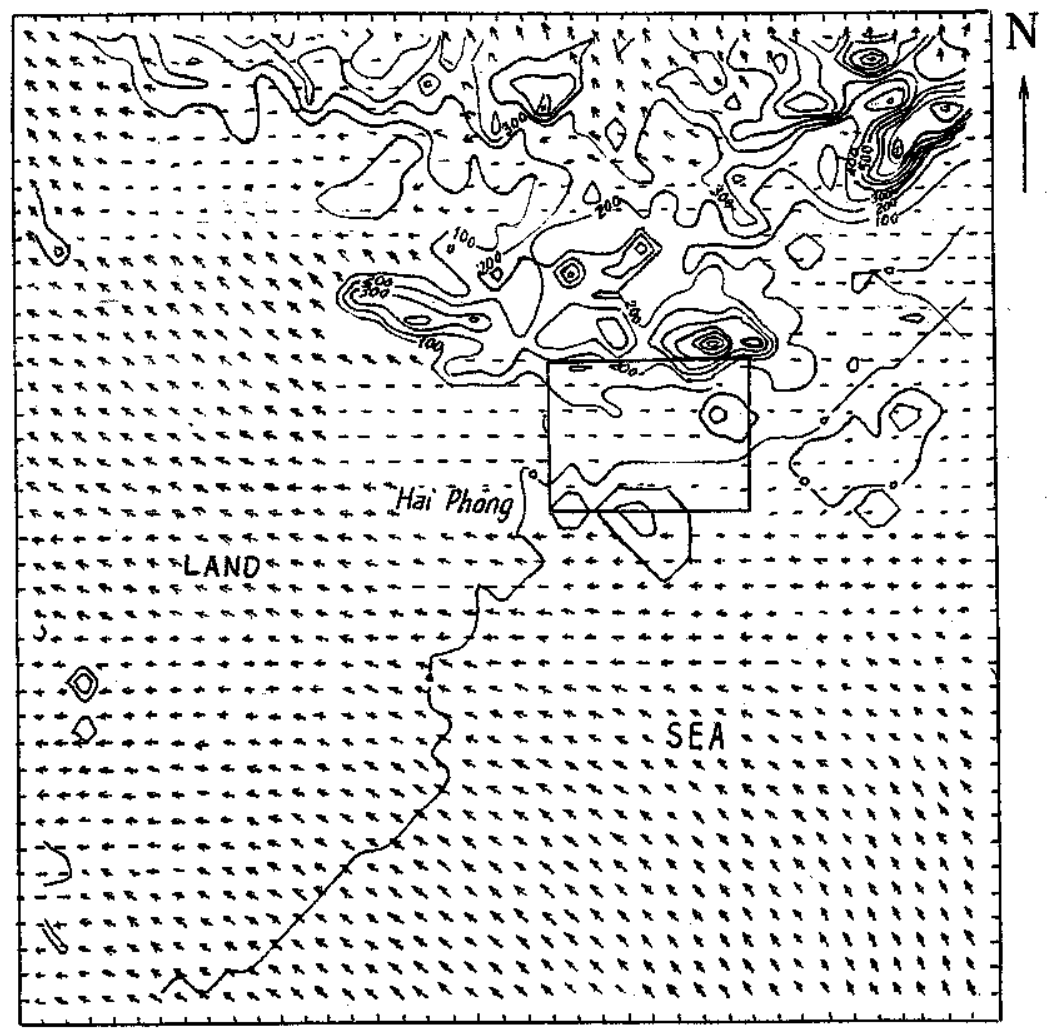

Fig. 4. Modeled wind fields $-06 \mathrm{~h}-10 \mathrm{~m}$ - Summer $\rightarrow 10 \mathrm{~m} / \mathrm{s}$

In order to investigate the wind field over complex terrain and pollutant propagation, 3 case studies (simulations) have been carried out accordingly to the following initial conditions:

Case study 1 (Figs 1-3)

\begin{tabular}{|c|c|c|c|c|c|}
\hline $\begin{array}{l}\text { Level } \\
(\mathrm{hPa})\end{array}$ & $\begin{array}{c}\text { Height } \\
\text { (m, Ground } \\
\text { surface-hPa) }\end{array}$ & $\begin{array}{l}\text { Wind direction } \\
\text {-Wind speed } \\
(\mathrm{m} / \mathrm{s})\end{array}$ & $\begin{array}{c}\text { Temperature } \\
\left({ }^{\circ} \mathrm{C}\right)\end{array}$ & $\begin{array}{c}\text { Specific } \\
\text { Humidity } \\
(\mathrm{g} / \mathrm{kg})\end{array}$ & $\begin{array}{c}\text { Relative } \\
\text { Humidity } \\
\text { (\%) }\end{array}$ \\
\hline $\begin{array}{l}\text { Ground } \\
\text { surface }\end{array}$ & 1022.0 & E-2 & 25 & 20.0 & 100 \\
\hline 1000 & 10 & SE-2 & 26.4 & 19.9 & 90 \\
\hline 850 & 1436 & SW-2.5 & 20.8 & 15.5 & 87 \\
\hline 700 & 3090 & WSW-5 & 10.8 & 11.4 & 98 \\
\hline 500 & 5830 & NW-7 & -3.9 & 5.6 & 100 \\
\hline 300 & 9710 & $\mathrm{NE}-30$ & -27.7 & 0.9 & 95 \\
\hline 200 & 12490 & $\mathrm{NE}-10$ & -48.5 & $x$ & $x$ \\
\hline 100 & 16690 & ENE-22 & -73.3 & $x$ & $x$ \\
\hline
\end{tabular}



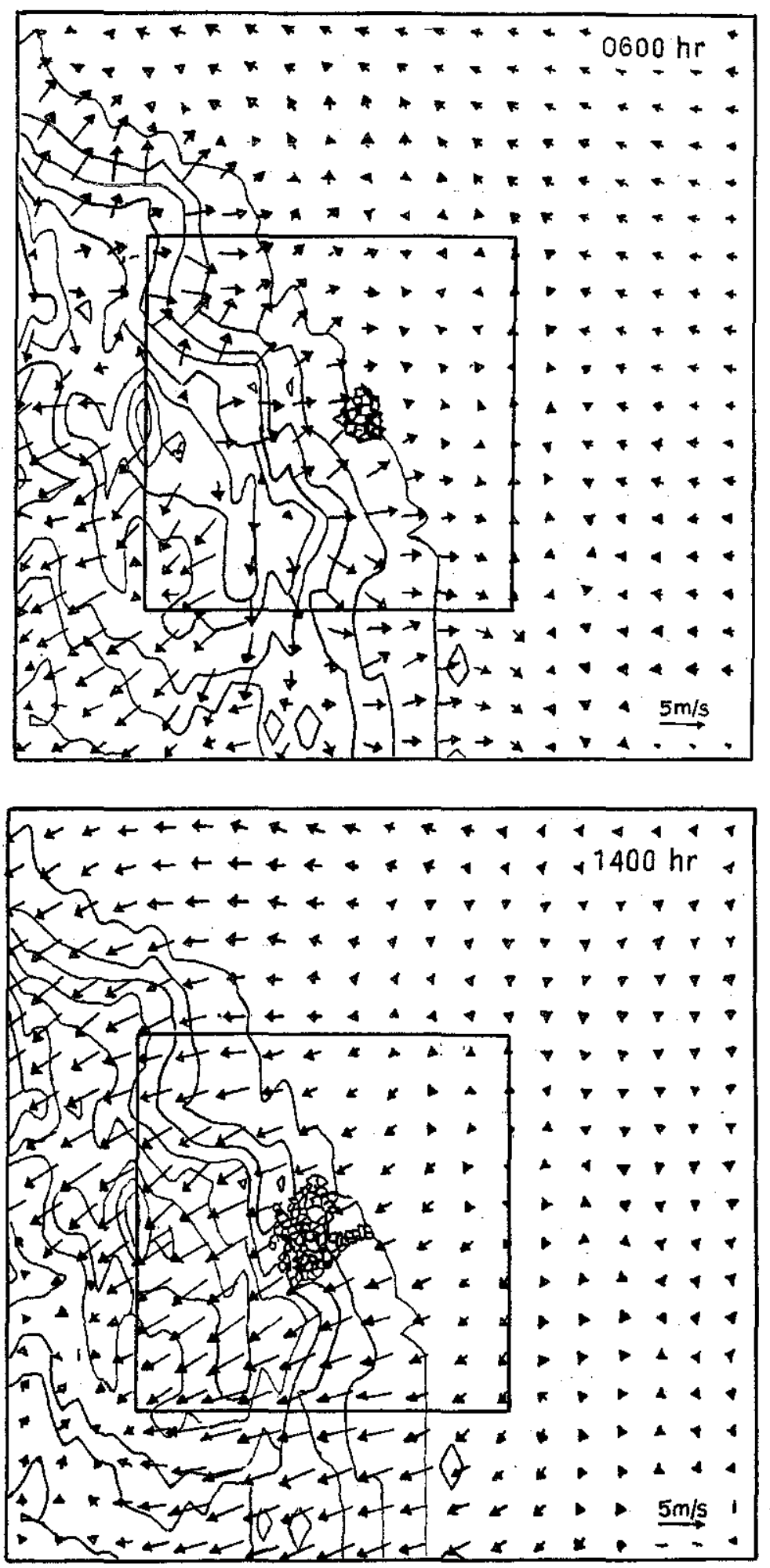

Fig. 5 

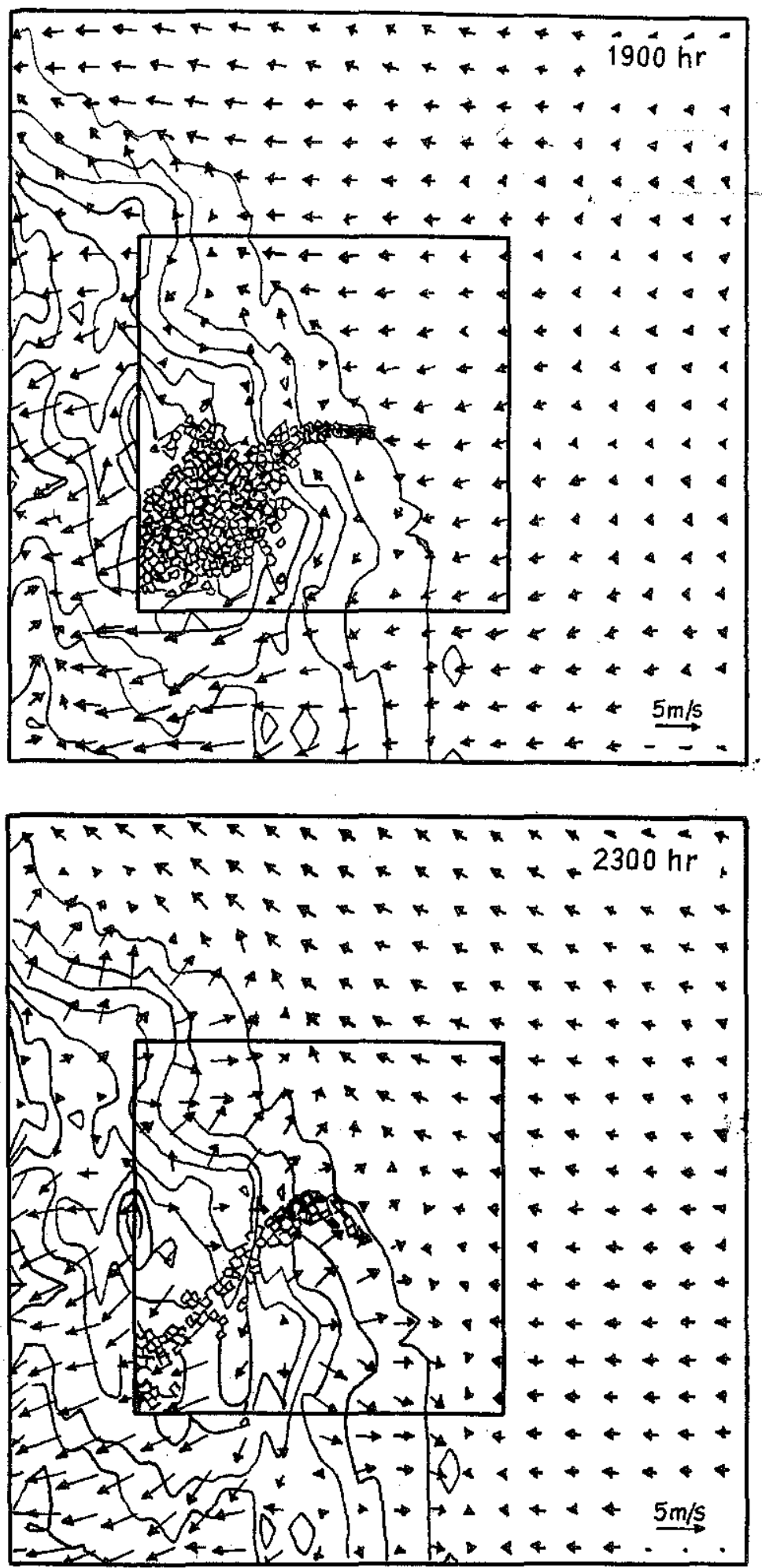

Fig. 5 (continued) 
Case study 2 (Fig. 4)

\begin{tabular}{|c|c|c|c|c|c|}
\hline $\begin{array}{l}\text { Level } \\
(\mathrm{hPa})\end{array}$ & $\begin{array}{c}\text { Height } \\
\text { (m, Ground } \\
\text { surface-hPa) }\end{array}$ & $\begin{array}{l}\text { Wind direction } \\
\text {-Wind speed } \\
\text { (m/s) }\end{array}$ & $\begin{array}{c}\text { Temperature } \\
\left({ }^{\circ} \mathrm{C}\right)\end{array}$ & $\begin{array}{c}\text { Specific } \\
\text { Humidity } \\
(\mathrm{g} / \mathrm{kg})\end{array}$ & $\begin{array}{c}\text { Relative } \\
\text { Humidity } \\
(\%)\end{array}$ \\
\hline Ground surface & 1022 & $\mathrm{NE}-2$ & 14 & 9.3 & 85 \\
\hline 1000 & 183 & NE-2 & 12.2 & 8.2 & 82 \\
\hline 850 & 1545 & $\mathrm{~N}-4$ & 10.2 & 8.7 & 90 \\
\hline 700 & 3140 & W-7 & 7.4 & 6.6 & 80 \\
\hline 500 & 5860 & WSW-17 & -8.7 & 1.1 & 30 \\
\hline 300 & 9650 & WSW-30 & -28.9 & 0.3 & 38 \\
\hline 200 & 12440 & WSW-30 & -48.3 & $x$ & $x$ \\
\hline 100 & 16670 & SW-12 & -76.9 & $x$ & $x$ \\
\hline \multicolumn{6}{|c|}{ Case study 3 (Fig. 5) } \\
\hline $\begin{array}{l}\text { Level } \\
(\mathrm{hPa})\end{array}$ & $\begin{array}{c}\text { Height } \\
\text { (m, Ground } \\
\text { surface-hPa) }\end{array}$ & $\begin{array}{l}\text { Wind direction } \\
\text {-Wind speed } \\
(\mathrm{m} / \mathrm{s})\end{array}$ & $\begin{array}{c}\text { Temperature } \\
\left({ }^{\circ} \mathrm{C}\right)\end{array}$ & $\begin{array}{c}\text { Specific } \\
\text { Humidity } \\
(\mathrm{g} / \mathrm{kg})\end{array}$ & $\begin{array}{c}\text { Relative } \\
\text { Humidity } \\
\text { (\%) }\end{array}$ \\
\hline Ground surface & 1012 & $\mathrm{SE}-2$ & 26 & 20.6 & 95 \\
\hline 850 & 1512 & ENE-5 & 16.1 & 12.7 & 96 \\
\hline 700 & 3142 & E-5 & 7.9 & 6.6 & 80 \\
\hline 500 & 5849 & ESE-5 & -5.9 & 1.1 & 30 \\
\hline 300 & 9660 & S-5 & -31.9 & 0.3 & 38 \\
\hline 200 & 12394 & $\mathrm{~S}-7.5$ & -54.1 & $x$ & $x$ \\
\hline 100 & 16546 & ESE-5 & -79.1 & $x$ & $x$ \\
\hline
\end{tabular}

These case studies are rather typical for the winter (case 2) and summer (case 1 and 3) seasons in Vietnam.

In Figs. 1-4 the calculated wind field on the height of $10 \mathrm{~m}$ from the ground at moment 6 h00 (Figs 1, 4) 11 h00 (Fig. 2) and 16h00 (Fig. 3) are presented. The inner square domain has a pollutant source at the center. The similar pictures for the central provinces around Dung Quat are presented in Fig. 5. In Figs 1-4 the vector fields are depicted with spatial interval of $5 \mathrm{~km}$, and in Fig. 5 - of $10 \mathrm{~km}$. From the figures it can be seen the place where the wind field is influenced by terrain. The calculation results show clearly that in the place far from the elevated terrain the wind field is relatively uniform and changes gradually from time to time. In the mountain area the wind field has non-uniform structure and change strongly (in direction and in value) from time to time. In this case to choice the common characteristic wind velocity for a big enough area is the question. This means the application of simplified models based on the stationary or pseudo stationary hypothesis can lead to considerable errors.

Comparing figures one with another indicates also the influence of sea breeze on the wind field distribution. In general this influence depends on different factors and in many cases plays significant role in the area of some tens $\mathrm{km}$ from the coastal line.

From the presented above figures we can see that although the synoptic wind is strong enough, the wind field changes significantly in both direction and values by terrain.

The calculation results show that the wind field in the complex terrain areas is relatively chaotic. The velocity vectors of the neighboring points can be strongly different in directions and values. And even in the $5 \mathbf{~ k m}$ radius area the wind can have opposite directions. In this and similar cases using simplified model based on Gaussian or Berliand conception even with modification is questionable. 


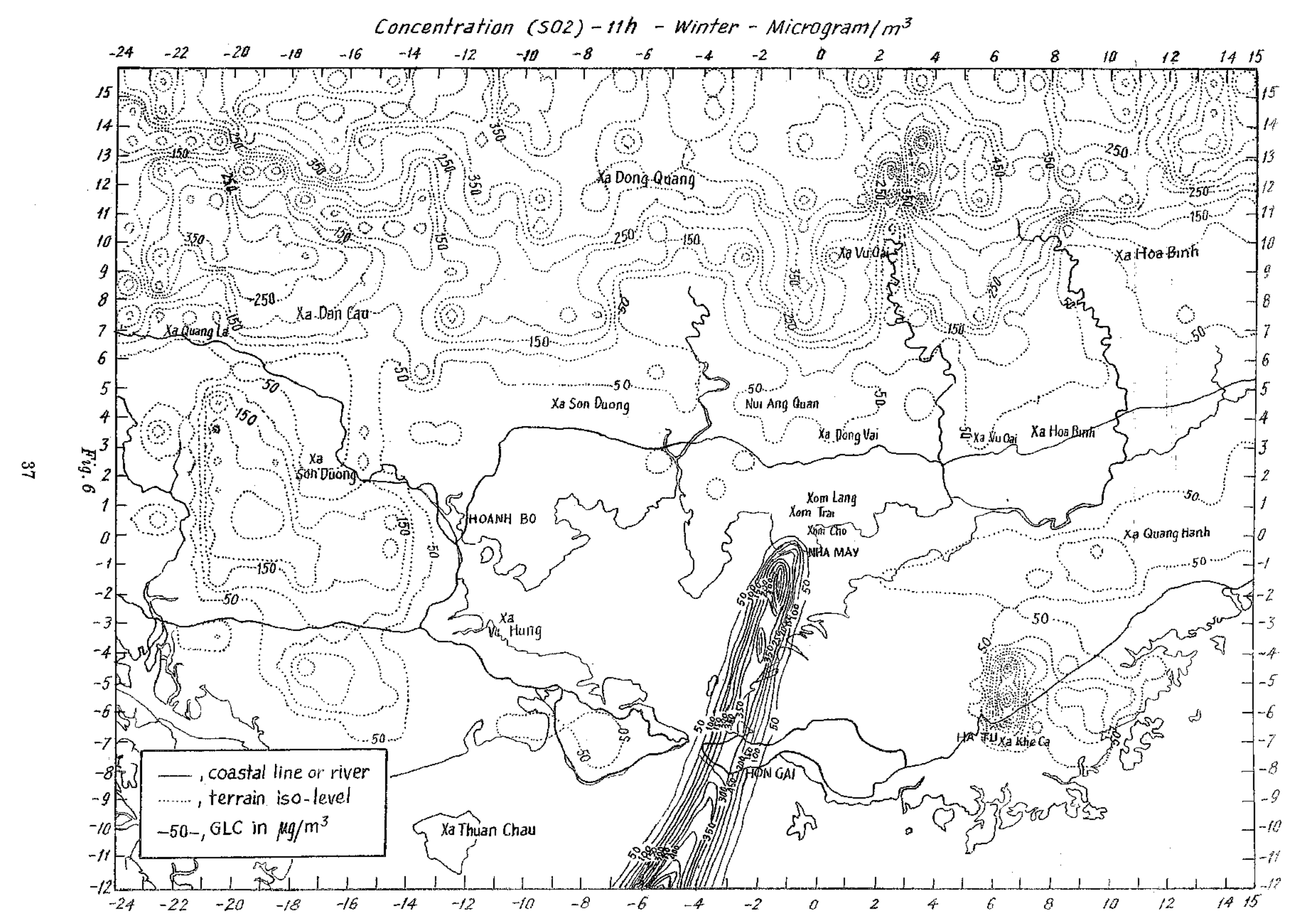




\section{Pollutant propagation}

Based on the obtained in 3 wind field the pollutant propagation in the air can be calculated and predicted.

As an example, in Fig. 6 the GLC (ground level concentration) distribution of $\mathrm{SO}_{2}$ for case study 1 is presented. In this case the proposal plant assumed has two stacks with a height of $100 \mathrm{~m}$, inside diameter of $3.96 \mathrm{~m}$ and volumetric flow of $14000 \mathrm{~m}^{3} / \mathrm{min}$ at $165^{\circ} \mathrm{C}$. The flue gas contains about $500 \mathrm{mg} \mathrm{SO}$ per a normal cubic meter. Because the wind field is simulated at any time moment, accordingly the pollution map can be obtained at any time and normally this map will change from time to time. The simulation results are necessary not only for environment pollutant assessment, but especially useful for designing and predicting purposes. In Fig. 5 all the particle release (with the view from the top) is presented for another case (case study 3) with following parameters: the stack height $h_{s}=100 \mathrm{~m}$, the inner radius of stack $r_{s}=2 \mathrm{~m}$, flue gas speed $v_{s}=15 \mathrm{~m} / \mathrm{s}$; the flue gas mass flow $q_{s}=1 \mathrm{~kg} / \mathrm{s}, T_{s}=100^{\circ} \mathrm{C}$. The plant site is near Dung Quat gulf (N. 15.5, E. 108.7).

It should be noted that the numerical package LADM simulates the three dimensional turbulent atmospheric motion (LADM-M) and pollutant transport and dispersion (LADM-P). It is a big simulator requested strong PC (Pentium 100 and later with $32 \mathrm{Mb}$ RAM and hard disk memory $\geq 2 \mathrm{~Gb}$ ) with a long running time $(\approx 20-30$ hours/1 case study). The package has the Graphical Information System convenient for presentation of the simulation results in a form of $1-D, 2-D$ and 3-D pictures.

The research is partly supported by National Basic Research Program in Natural Sciences.

\section{REFERENCES}

1. Lyons T. J. and Scott W. D. Principles of Air Pollution Meteorology. Belhaven Press, London 1990.

2. Berliand M. Modern Problems of Atmospheric Diffusion and Air Pollution, Leningrad 1995.

3. Physick W. L., Noenan J. A., McGregor J. L., Hurley P. J., Abbs D. J., and Manin P.C. LADM - a Lagrangian Atmospheric Dispersion Model. CSIRO, Research Technical Paper No 24, 1994.

Received September 18, 1997

\section{TRƯỜNG GIÓ VÙNG ĐỊA HìnH PHỨC TẠP VA MÔ HìnH HÓA CHẤT LỰ̛NG MÔI TRƯờNG KHÔNG KHÍ}

Trường gió là thành phần thứ hai trọng chuối: Ngừ̀n - Tải - Đối tượng và đóng vai trò quan trọng trong các quá trình ô nhiểm khí quyển. Tuy nhiên việc xác định được chính xác trường gió để sư dụng trong các mô hình số về ô nhiễm không khí luôn là một vấn đề khó, đặc biệt đối với những vùng có địa hùnh phức tạp như vùng núi hay vùng chịu ảnh hướng gió biển. Trong bài báo trình bày một số kết quá mô phỏng trường gió 3 chiều và tính toán chất lượng môi trường không khí sử dụng mô hình dỏng rối khí quyển và tán xạ theo quan điểm Lagrange cho một số tính ớ đông bắc (Hải Phòng, Quáng Ninh) và miền trung (Dung quất) Việt Nam trong một số trường hợp nghiên cún. Kết quả tính toán được thu nhận trên máy tính Pentium 100 với 32 Mb RAM. 